\title{
First report of Trypanosoma vivax outbreak in dairy cattle in Sáo Paulo state, Brazil
}

\author{
Primeiro relato de surto por Trypanosoma vivax em vacas leiteiras no estado de São Paulo, Brasil \\ Fabiano Antonio Cadioli ${ }^{1 *}$; Patrícia de Athayde Barnabé2; Rosangela Zacarias Machado³; \\ Márcia Cristina Alves Teixeira ${ }^{3}$; Marcos Rogério André3; Paulo Henrique Sampaio ${ }^{3}$; Otávio Luiz Fidélis Junior ${ }^{1}$; \\ Marta Maria Geraldes Teixeira ${ }^{4}$; Luiz Carlos Marques ${ }^{3}$ \\ 'Departamento. Clínica, Cirurgia e Reprodução Animal, Faculdade de Odontologia e Curso de Medicina Veterinária,
Universidade Estadual Paulista - UNESP, Araçatuba, SP, Brasil
${ }^{2}$ Curso de Medicina Veterinária, Fundação Educacional de Andradina - FEA, Andradina, SP, Brasil
${ }^{3}$ Faculdade de Ciências Agrárias e Veterinárias, Universidade Estadual Paulista - UNESP, Jaboticabal, SP, Brasil
${ }^{4}$ Departamento de Parasitologia, Instituto de Ciências Biomédicas, Universidade de São Paulo - USP, São Paulo, SP, Brasil
}

Received August 17, 2011

Accepted February 14, 2012

\begin{abstract}
This is the first description of a Trypanosoma vivax outbreak in the state of São Paulo (municipality of Lins). Fever, jaundice, decreased milk production, weight loss, profuse diarrhea, abortion, anemia, leukocytosis and hyperfibrinogenemia were observed in the affected animals. Thirty-one cows and calves died out of a total of 1080 in the herd. Three cows showed neurological symptoms like dysmetria, ataxia, muscle weakness, ptyalism, lymph node enlargement and submandibular edema. Flagellated hemoparasites were observed in blood smears. The species was diagnosed as T. vivax by means of PCR. This T. vivax strain showed resistance to diaminazene aceturate and the infection spread quickly at the herd. From the ELISA test, 599 serum samples $(98.36 \%)$ were positive for anti-T. vivax IgG antibodies. This outbreak occurred during a very dry period, which indicates that other factors were involved in the outbreak, such as absence of tabanids and large populations of Haematobia irritans and Stomoxys calcitrans. The increases in these populations may have been due to the use of biosolid waste from sugar and ethanol plants in the sugarcane plantations surrounding the dairy farm.
\end{abstract}

Keywords: Bovine, trypanosomiasis, natural infection, anemia, T. vivax, PCR.

\section{Resumo}

Esta é a primeira descrição de um surto de Trypanosoma vivax ocorrido no Estado de São Paulo, no município de Lins. Animais acometidos apresentaram febre, icterícia, diminuição da produção de leite, perda de peso, diarreia profusa, abortos, anemia, leucocitose e hiperfibrigenemia. Foram registrados 31 óbitos de vacas e bezerros em 1.080 bovinos no total. Três vacas apresentaram sintomatologia nervosa, como dismetria, ataxia e fraqueza muscular, além de ptialismo, aumento de linfonodos e edema submandibular. Hemoparasitas flagelados foram observados em esfregaços sanguíneos, e a espécie de tripanossomo foi diagnosticada como T. vivax por PCR. A cepa de T. vivax mostrou ser resistente ao tratamento com aceturato de diaminozeno e a infecção disseminou rapidamente no rebanho. Pelo ELISA, observou-se que 98,36\% (599) das amostras de soro colhidas apresentaram títulos positivos para IgG anti-T. vivax. O surto ocorreu em condições de baixa precipitação pluviométrica, fato que indica que outros fatores estavam envolvidos na ocorrência desse surto, como a ausência de tabanídeos e a grande presença de Haematobia irritans e Stomoxys calcitrans, cujo aumento populacional pode ser devido ao uso de resíduos de usinas de açúcar e álcool nos canaviais que circundavam a granja leiteira.

Palavras-chave: Bovino, tripanossomíase, infecção natural, anemia, T. vivax, PCR. 


\section{Introduction}

The hemoprotozoan Trypanosoma vivax infects a wide range of wild and domestic ungulates and causes important economic losses in cattle herds in tropical areas of Africa, Central America and South America (GARDINER, 1989; JONES; DÁVILA, 2001; OSÓRIO et al., 2008). In South America, it was probably introduced around 1830 through infected cattle from Africa, and mechanical transmission occurs by means of tabanids such as Stomoxys calcitrans and probably other biting flies (SILVA et al., 1996; VENTURA et al., 2001; JONES; DÁVILA, 2001; OSÓRIO et al., 2008). Natural infection with T. vivax has been reported in cattle in several countries: Surinam, Venezuela, Colombia, Brazil, Bolivia, Paraguay, Peru and Costa Rica (CLARKSON, 1976; SILVA et al., 1998b; QUISPE et al., 2003; GARCIA et al., 2005; OSÓRIO et al., 2008; OLIVEIRA et al., 2009).

The main clinical signs observed in cattle naturally infected with T. vivax have been intermittent fever, anemia, abortion, apathy, inappetence, diminished milk production, progressive weight loss and, occasionally, death (SILVA et al., 1996, 1998a; SILVA; DÁVILA, 2001; BATISTA et al., 2007, 2009; OSÓRIO et al., 2008). However, infected cattle may sometimes be asymptomatic (GARDINER, 1989; PAIVA et al., 2000; QUISPE et al., 2003; DÁVILA et al., 2003; BATISTA et al., 2007, 2009). If no treatment were made, the estimated financial impact of bovine trypanosomiasis due to T. vivax occurring in the Brazilian Pantanal region (states of Mato Grosso and Mato Grosso do Sul) would be $17 \%$ of the total herd value (SEIDL et al., 1997).

Although outbreaks in cattle due to T. vivax may be sporadic in endemic areas of Brazil, especially in the Pantanal, recent reports have indicated that T. vivax is spreading across Brazil, thereby causing severe disease in cattle, sheep, goats and, more sporadically, in horses, in the Northeastern and Southern regions (BATISTA et al., 2007, 2009; DA SILVA et al, 2009, 2011). Recently, the first outbreak of trypanosomiasis due to T. vivax in Southeastern Brazil, in the state of Minas Gerais, was reported by Cuglovici et al. (2010). However, the state of São Paulo state, which is located in Southeastern Brazil bordered by Mato Grosso do Sul and Minas Gerais, was until now considered to be free from T. vivax. In this study, we report the first cases of T. vivax infection in the state of Sáo Paulo, in an outbreak of severe infection in dairy cows that showed unusual epidemiological factors.

\section{Material and Methods}

\section{Outbreak characterization and clinical signs}

The $T$. vivax outbreak reported here occurred on a dairy farm with 1,080 Girolando and Holstein animals, in a semi-intensive production system. The farm is located at Lins ( $-21^{\circ} 40^{\prime} 43^{\prime \prime}$ latitude, $-49^{\circ} 44^{\prime} 23^{\prime \prime}$ longitude), in the state of Sáo Paulo and has an area of 350 ha. It is isolated from other farms by a large sugarcane plantation that surrounds it.

Before our first visit, the veterinarian of this farm reported between July and August 2008 that eight cows showed anemia, abortion, apathy, progressive weight loss, diarrhea and diminished milk production; two of the cows first affected died. The veterinarian and the farm manager were interviewed in order to obtain information about health problems among the herd, movement of animals into and out from the farm and sanitary measures taken at that time. In order to better characterize the outbreak, the facilities and herd management were inspected for factors that might have contributed towards the spread of T. vivax.

\section{Parasite detection}

Direct observation: At our first visit to the farm, in September 2008, 12 cows showing clinical signs were examined and blood samples were collected from the jugular vein using the Vacutainer system with EDTA, for direct observation of fresh blood samples, using an optical microscope with a 40x objective. Blood smears from each sample were stained with May-Grünwald-Giemsa for morphological analysis on the trypanosomes.

Biological proof: To perform a biological proof, blood samples were mixed in equal volume with Alsever's solution, and were then inoculated intraperitoneally into Wistar rats $(0.5 \mathrm{~mL} /$ rat $)$. Three rats were used for each sample. A parasitemic cow blood sample containing approximately $2.0 \times 10^{6}$ parasites in $2.5 \mathrm{~mL}$ was mixed in equal volume with Alsever's solution and intravenously inoculated into a two-month-old sheep. After inoculation, one blood drop from the tail of each inoculated Wistar rat was examined every third days until the $30^{\text {th }}$ DPI (Day Post-Inoculation), searching for trypomastigote forms, and sheep blood samples were examined daily until the $20^{\text {th }}$ DPI, using Woo's technique (WOO, 1970).

\section{Hemogram}

Blood samples were collected from the jugular vein of 12 cows showing clinical signs, in order to perform blood cell counts using an automatic counter (ABX Micros ABC Vet ${ }^{\circ}$ ). Total protein and fibrinogen were determined, respectively, by refractometry and the heat-denaturation method.

\section{Serological tests}

During a second visit to the farm, in December 2008, 609 blood samples representing $58.05 \%$ of the herd were collected from cows in different production segments. Concomitantly, 20 serum samples from adult cows from Ivinhema farm (in Mato Grosso do Sul) were obtained. The serum samples were frozen at $-20{ }^{\circ} \mathrm{C}$ and stored for further use in serological assays.

Antigen preparation and the ELISA test were performed as described by Machado et al. (1997) and Aquino et al. (2010), using sheep blood experimentally infected with $T$. vivax. Plates were coated with $5 \mu \mathrm{g}$ of soluble bovine antigen. The bovine test serum samples were diluted $1: 100$. Alkaline phosphatase conjugated with rabbit IgG anti-bovine IgG (SIGMA A-0668) was diluted $1: 30,000$. Positive $(n=10)$ and negative $(n=10)$ control serum samples were tested under these conditions. Positive serum samples were obtained from animals that had previously been experimentally infected with $T$. vivax. All the control and 
test serum samples were analyzed in duplicate. To determine the ELISA cutoff, the mean absorbance of the tested serum samples was grouped into ELISA levels (EL) ranging from 0 to 9. The maximum limit of level 0 was determined as the mean absorbance of the negative control serum samples with the addition of twice the standard deviation, and subsequent levels were determined as increments of $35 \%$ as determined by Machado et al. 1997 . In this case, the mean absorbances for the positive and negative control serum samples were $0.885 \pm 0.428$ and $0.131 \pm 0.030$, respectively. Serum samples with EL > 1 were considered positive.

\section{PCR technique}

Whole-blood samples from clinically ill animals were collected during the first and second visits and were frozen in liquid nitrogen for further tests using a T. vivax-specific PCR assay, and to preserve the Trypanosoma strain. DNA extraction from whole blood was carried out using a QIAamp DNA Blood Mini Kit (Qiagen ${ }^{\circ}$ ) and the extracted DNA was identified and stored at $-20^{\circ} \mathrm{C}$ for further use. The extraction and the PCR, which targeted gene sequences encoding for CatL-like enzymes, were performed as described by Cortez et al. (2009). This PCR technique can distinguish T. vivax from T. evansi, T. theileri and other trypanosome species.

\section{Statistical analysis}

The ELISA data were subjected to basic descriptive statistical analyses.

\section{Results and Discussion}

\section{Outbreak characterization and clinical signs}

As reported by the veterinarian and the farm manager, the first cases occurred in July 2008 in two cows that had been reared on Ivinhema farm, Mato Grosso do Sul (MS). These, along with another 19 cows from MS, were transferred to the farm in Lins in June 2008, at which time these animals were described as "apparently healthy". No serological or hematological tests were performed on these cows prior to transportation to Lins. Between July and August 2008 (Figure 1), two cows from MS died and eight cows from Lins showed anemia, abortion, apathy, progressive weight loss, diarrhea and diminished milk production. These were presumptively treated with diaminazene aceturate $(3.5 \mathrm{mg} / \mathrm{kg})$ and supplemented with vitamin B12. In September 2008, one cow died and 11 out of the 1,077 cattle on the farm in Lins showed loss of appetite, accentuated weight loss, fever, keratitis and nasal discharges.

From October to November 2008, 43 out of the 1,052 cattle on the farm in Lins presented clinical signs. Loss of appetite, fever and pale mucous membranes were seen in 18 cows. Severe anemia, jaundice, abortion, hyperemia and petechiation of the conjunctiva, keratitis, cervical lymph node enlargement, nasal and vaginal discharges, diminished milk production, diarrhea and accentuated weight loss were observed in 25 animals. In addition, three of the 18 cows presented neurological symptoms of dysmetria, ataxia and muscle weakness, mainly in the hind limbs. One of these cows also showed ptyalism, lymph node enlargement and submandibular edema. Five cows had profuse diarrhea for some weeks.

A total of five cows and 20 calves died between October and November due to severe anemia and very poor body conditions. All three of the cows that showed neurological symptoms died after one to three weeks, in December. Among the calves, the clinical signs initially observed were loss of appetite, fever and diarrhea, with faster evolution to severe anemia, jaundice and death after one to two weeks.

The clinical signs reported in this study in cows infected with T. vivax have also been described in outbreaks of trypanosomiasis in the Pantanal region (SILVA et al., 1996, 1998a, b; SILVA; DÁVILA, 2001); Minas Gerais (CARVALHO et al., 2008); French Guiana (DESQUESNES; GARDINER, 1993); Colombia (OTTE et al., 1994); and Venezuela (CLARKSON et al., 1971; TAMASAUKAS et al., 2000). Similarly, on a dairy farm in the state of Paraiba, cows infected with T. vivax were seen to present neurological signs before they died (BATISTA et al., 2007). In this previous study and in the outbreak reported here, the cows showing severe symptoms and neurological disturbances were all dairy cattle of the Holstein or Girolando breeds. Although the Pantanal region of Brazil is an endemic region where T. vivax infection is mostly cryptic in bovids, mortality was observed in some of the outbreaks among cattle reported in this region (SILVA; DÁVILA, 2001; OSÓRIO et al., 2008). On the other hand, other studies did not detect any clinical signs in animals infected with T. vivax in the Pantanal (PAIVA et al., 2000; VENTURA et al., 2001; DÁVILA et al., 2003). In the first T. vivax outbreak reported in the Northeastern region of Brazil, 130 dairy Holstein cows were found to be infected, and 11 of them died (BATISTA et al., 2007). In Brazil, mortality has only been shown to be common in cattle herds with no previous contact with T. vivax (BATISTA et al. 2007; DA SILVA et al., 2009, 2011; CUGLOVICI et al., 2010).

Several authors have indicated that there is an association between trypanosome infection and the rainy season, when bloodsucking insects are more abundant, with increasing prevalence of T. vivax in South America (GARDINER, 1989; TAMASAUKAS et al, 2000; SILVA et al., 1996, 1998b; SILVA; DÁVILA, 2001; BATISTA et al., 2007). Similar observations about the rainy season and T. vivax outbreaks were made by Batista et al. (2009) in the Northeastern region of Brazil, and by Cuclovici et al. (2010) in Minas Gerais, on dairy farms. In contrast with previous outbreaks described in Brazil, the mean rainfall values for the region of the outbreak reported here were below normal for June to December 2008, with no rainy days between June and October and a mean temperature of $23.6^{\circ} \mathrm{C}$ (CIIAGRO, 2011). Rodríguez-Batista et al. (2005) observed that there was a strong positive correlation between $S$. calcitrans and temperature, especially above $20^{\circ} \mathrm{C}$, and a weak positive correlation between this fly population and rainfall in Minas Gerais. This indicates that while the rainy season is important, it may not have been a determining factor for the T. vivax outbreak that occurred in the state of São Paulo, while temperature was. 


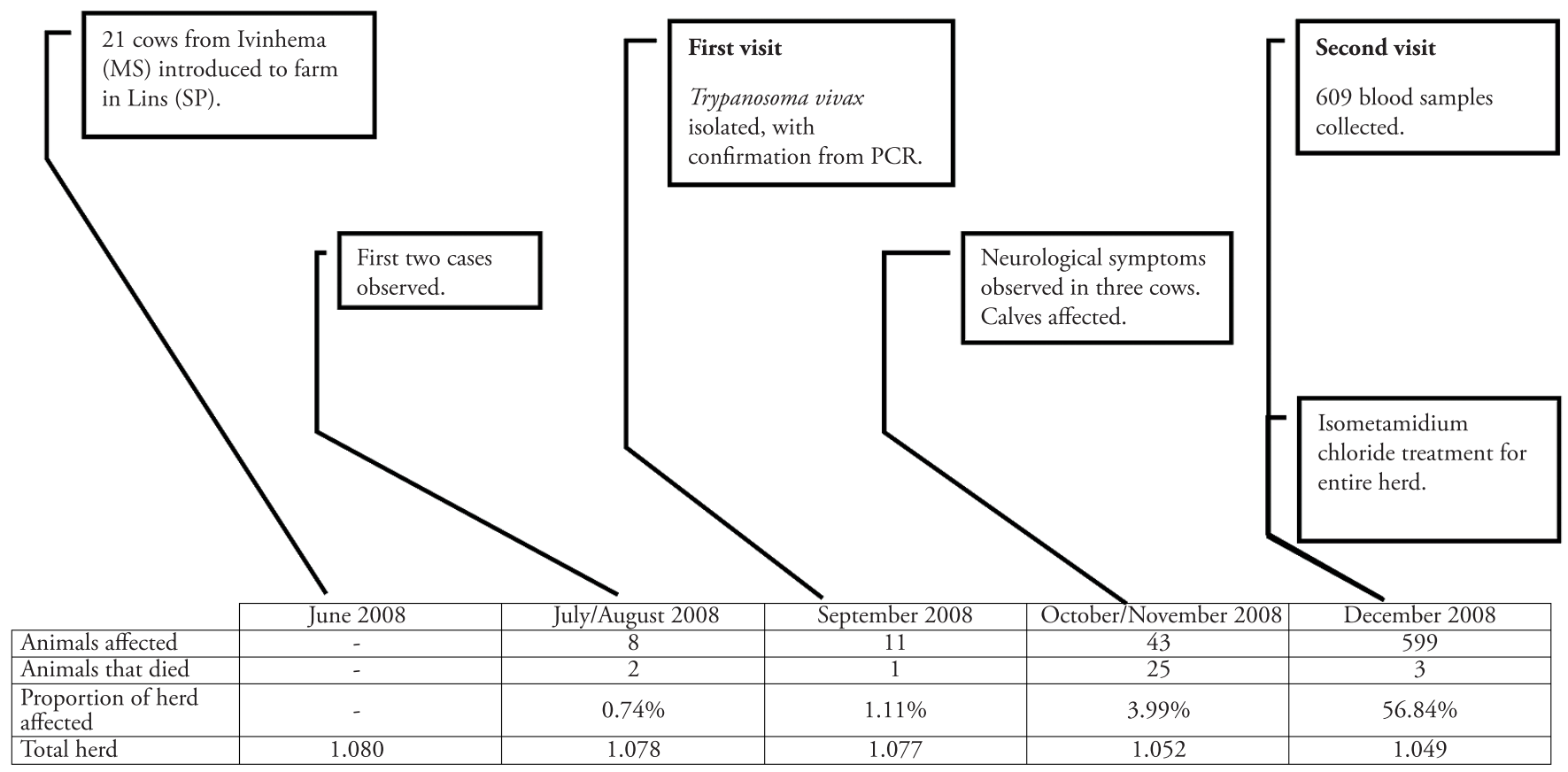

Figure 1. Timeline of the first Trypanosoma vivax outbreak that occurred in the state of São Paulo (SP), Brazil (MS = state of Mato Grosso do Sul).

In our visits to the farm in Lins, we never observed any large population of tabanids, which are the flies implicated as the main vectors of T. vivax in South America, especially in the Pantanal region (PAIVA et al., 2000). However, large numbers of Haematobia irritans and Stomoxys calcitrans were detected during all the visits to the farm. Batista et al. (2007) drew attention to the possible role of $H$. irritans (horn flies) in trypanosome transmission in an outbreak reported in the state of Paraiba, Brazil, and Oliveira et al. (2009) and Cucliovici et al. (2010) highlighted S. calcitrans in outbreaks of T. vivax in Costa Rica and Minas Gerais, respectively. According to these previous observations and the data from the present study, $H$. irritans and $S$. calcitrans may play an important role in T. vivax transmission.

The manure and moisture commonly seen near milking facilities, plus the organic waste produced by the large sugarcane plantation surrounding the farm in Lins may have provided suitable organic matter to attract flies and favor reproduction, independent of rainfall levels. In addition, at high ambient temperatures, as observed in the Lins region, production of adult flies associated with biosolid waste is increased (DADOUR; VOSS, 2009). Rodríguez-Batista et al. (2005) observed higher S. calcitrans concentrations near barns and other farm constructions than in grass fields or woods on the same farm over a one-year period. Outbreaks of $S$. calcitrans were reported at dairy and beef cattle feedlots with nearby sugarcane plantations that were fertilized with organic waste from ethanol plants in the same region of the state of São Paulo as the outbreak of the present report (ODA; ARANTES, 2010). Therefore, the procedure used for sugarcane ethanol production may, over time, allow increases in vector populations that can spread hemoparasites more efficiently, independently of weather conditions.

Fomites, especially contaminated needles, can add strength to T. vivax transmission. In the particular case of the outbreak on the farm in Lins, after the first animals infected with T. vivax had been diagnosed, greater attention was paid to avoidance of potential transmission by fomites, especially needles, although the number of infected animals continued to increase.

In the Brazilian Pantanal (MS), T. vivax can be considered to be a secondary agent, given that morbidity and mortality is mostly attributable to primary agents such as Anaplasma marginale, Babesia spp., plant intoxication and deficient management conditions (PAIVA et al., 2000). However, in non-endemic areas, including Northeastern and Southeastern Brazil, where herds are immunologically naïve in relation to this hemoprotozoan, T. vivax has become a primary agent and can cause wasting disease and high levels of mortality (BATISTA et al., 2007, 2009; DA SILVA et al., 2011). All of the abovementioned factors probably contributed towards increasing the rate of T. vivax transmission and were triggering factors for outbreak that we reported in this study.

\section{Parasite detection}

Direct observation: At our first visit to the farm in Lins, only two blood samples were positive for Trypanosoma sp. on direct examination, but all 12 samples examined showed trypomastigotes in stained blood smears, although the sensitivity of blood smears for diagnosing infections due to T. vivax is about 10\% (QUISPE et al., 2003). The most highly parasitized cow had been raised at a farm in MS, and presented persistent anemia and weight loss. This animal was the first to show trypomastigotes in this survey. The trypanosomes found in blood smears were morphologically aberrant and pleomorphic, frequently showing vacuolization, which was presumably induced by previous recurrent use of diaminazene aceturate. Morphological alterations of T. vivax induced by this treatment were also observed by Da Silva et al. (2011). 
Occurrences of anaplasmosis and babesiosis were reported as common issues in on the farm in Lins, and therefore diaminazene aceturate was used previously by the veterinarian, at the first signs of anemia and before laboratory confirmation. The treated animals at first appeared to recover, with no detectable parasitemia for 20 days to two months. However, new trypomastigotes were observed again in blood smears and these animals became clinically ill. Subsequent treatments with a higher dose of diaminazene aceturate $(7.0 \mathrm{mg} / \mathrm{kg})$ had no effect on the $T$. vivax populations in the clinically ill animals and at least three cows died after recurrent treatments, which indicates that resistance to this product developed.

Biological proof: Trypomastigotes were detected in inoculated sheep blood samples on the $4^{\text {th }}$ to $6^{\text {th }}$ DPI and, after a period showing no parasitemia, on the $10^{\text {th }}$ to $16^{\text {th }}$ DPI. The Wistar rats did not present parasitemia during the 30 days of observation, as expected for T. vivax.

Trypanosomes from the blood of the experimentally infected sheep were observed in stained blood smears, and showed a body shape and a rounded kinetoplast in the terminal position that were compatible with T. vivax.

\section{Hemogram}

Blood tests on 12 clinically ill cows that were positive in the parasitological test showed some individual alterations like decreased RBC, PCV and hemoglobin levels, and increased total protein and fibrinogen levels (Table 1). Leukopenia was observed in three hemograms, with marked anemia. Several hemograms showed leukocytosis, some with increased total protein and fibrinogen levels. Anemia is the commonest find in cattle with clinical signs of T. vivax infection (SILVA et al., 1998b; BATISTA et al., 2007; OSÓRIO et al., 2008), sometimes associated with leukopenia (CARVALHO et al., 2008). In infections caused by trypanosomes, anemia has been attributed to bone marrow depletion and deposition of immune complexes on the erythrocyte surface, thus resulting in increased erythrophagocytosis, as well as to other factors such as enhanced neuraminidase and reduced cholinesterase activity and lipid peroxidation (MURRAY; DEXTER, 1998; DA SILVA et al., 2011). Elevated total protein levels were observed by Da Silva et al. (2009) in a cow infected by T. vivax in the state of Rio Grande do Sul, Southern Brazil. Increased leukocytosis and fibrinogen levels have not previously been reported in cattle infected with $T$. vivax.

\section{Serological tests}

In a survey for T. vivax infection carried out on the farm in Lins in December 2008, an ELISA test was performed using an antigen of this species and showed that 599 (98.36\%) out of 609 blood serum samples examined were positive for anti-T. vivax IgG antibodies (Table 2). This result indicated that the entire herd could be considered to be virtually infected. The high frequency of anti-T. vivax IgG antibodies indicated that efficient transmission of this hemoparasite was occurring on the farm in Lins. All of the 20 serum samples from adult cows that were obtained on the farm in MS were considered to be positive in an ELISA test (EL > 1; Table 3$)$, which suggested that the herd had been in contact with $T$. vivax. The data from this study reinforced the notion that T. vivax can quickly become widespread in herds with no previous contact with this hemoprotozoan, even if the cows presented a good nutritional status, and that naïve animals can show severe disease and high mortality. Taking the view that the infected cows from MS were the source of the parasite introduced into the herd in June 2008, the data from this study indicated that after around six months, all the animals on the farm would have to be considered to be infected by $T$. vivax.

\section{PCR technique}

All the 12 bovine whole-blood samples collected at our first visit to the farm in Lins were tested by means of PCR. This showed a 177 bp amplified DNA fragment, which confirmed the diagnosis of T. vivax infection (CORTEZ et al., 2009). Analyses on CatL-amplified sequences indicated that there was high genetic similarity among T. vivax isolates from Northern, Central and Southern Brazil that have been found circulating in cattle, water buffaloes, sheep, goats and horses (CORTEZ et al. 2006, 2009; DA SILVA et al., 2011).

\section{Final Remarks}

The situation on the farm in Lins began to return to normality in December 2008, almost six months after the first cases of T. vivax infection were diagnosed. This return to normality began after the farm's veterinarian started to treat all the animals with two isometamidium chloride applications at a dosage of $1.0 \mathrm{mg} / \mathrm{kg}$,

Table 1. Red blood cells (RBC), packed cell volume (PCV), hemoglobin (Hb), mean corpuscular volume (MCV), mean corpuscular hemoglobin concentration (MCHC), white blood cells (WBC), total protein (TP) and fibrinogen (Fbr) values for 12 cows that were naturally infected with Trypanosoma vivax, in an outbreak at Lins (SP), Brazil.

\begin{tabular}{|c|c|c|c|c|c|c|c|c|c|c|c|c|c|}
\hline & Reference* & Cow 1 & Cow 2 & Cow 3 & Cow 4 & Cow 5 & Cow 6 & Cow 7 & Cow 8 & Cow 9 & Cow 10 & Cow 11 & Cow 12 \\
\hline $\mathrm{RBC}\left(\times 10^{12} / \mathrm{L}\right)$ & $5.0-10.0$ & 4.9 & 3.16 & 3.24 & 3.3 & 2.91 & 6.92 & 6.61 & 6.47 & 4.94 & 5.02 & 4.97 & 4.87 \\
\hline PCV (L/L) & $0.24-0.46$ & 0.17 & 0.17 & 0.17 & 0.17 & 0.17 & 0.35 & 0.33 & 0.33 & 0.26 & 0.27 & 0.26 & 0.23 \\
\hline $\mathrm{Hb}(\mathrm{g} / \mathrm{L})$ & $80-150$ & 58 & 55 & 57 & 58 & 52 & 115 & 111 & 111 & 82 & 85 & 82 & 76 \\
\hline MCV (fL) & $40-60$ & 34.7 & 53.8 & 52.5 & 51.5 & 58.4 & 50.6 & 49.9 & 51.0 & 52.6 & 53.8 & 52.3 & 47.2 \\
\hline MCHC (g/L) & $300-360$ & 341 & 324 & 335 & 341 & 306 & 329 & 336 & 336 & 315 & 315 & 315 & 330 \\
\hline WBC $\left(\times 10^{9} / \mathrm{L}\right)$ & $4.0-12.0$ & 5.3 & 3.2 & 4.9 & 3.85 & 2.45 & 18.2 & 13.8 & 13.35 & 14.3 & 13.5 & 14.5 & 11.5 \\
\hline $\mathrm{TP}(\mathrm{g} / \mathrm{L})$ & $57-81$ & 72 & 70 & 74 & 72 & 74 & 92 & 92 & 90 & 72 & 72 & 70 & 70 \\
\hline Fbr (g/L) & $2-7$ & 4 & 2 & 4 & 2 & 2 & 5 & 8 & 8 & 10 & 8 & 8 & 4 \\
\hline
\end{tabular}

${ }^{*}$ References values (RADOSTITS et al., 2007). 
Table 2. ELISA levels, absorbance (Abs) range, number and percentage of serum samples from cattle that were naturally infected with Trypanosoma vivax in Lins, SP.

\begin{tabular}{cccc}
\hline ELISA levels & Abs range & $\begin{array}{c}\text { Number of } \\
\text { animals }\end{array}$ & Percentage \\
\hline 0 & $0-0.193$ & 10 & 1.64 \\
1 & $0.194-0.261$ & 2 & 0.33 \\
2 & $0.262-0.328$ & 2 & 0.33 \\
3 & $0.329-0.396$ & 23 & 3.78 \\
4 & $0.397-0.463$ & 33 & 5.42 \\
5 & $0.464-0.531$ & 38 & 6.24 \\
6 & $0.532-0.598$ & 43 & 7.06 \\
7 & $0.599-0.666$ & 58 & 9.52 \\
8 & $0.667-0.733$ & 46 & 7.55 \\
9 & $\geq 0.734$ & 354 & 58.13 \\
\hline
\end{tabular}

Table 3. Bovine serum samples from Ivinhema farm (MS) tested by means of ELISA for anti-Trypanosoma vivax IgG antibodies.

\begin{tabular}{cccc}
\hline Serum sample & Abs* & E.L.** & RESULT \\
\hline MS1 & 1.441 & 9 & Positive \\
MS2 & 1.438 & 9 & Positive \\
MS3 & 1.065 & 9 & Positive \\
MS4 & 0.647 & 7 & Positive \\
MS5 & 1.940 & 9 & Positive \\
MS6 & 0.727 & 8 & Positive \\
MS7 & 0.749 & 9 & Positive \\
MS8 & 1.462 & 9 & Positive \\
MS9 & 1.552 & 9 & Positive \\
MS10 & 0.497 & 5 & Positive \\
MS11 & 0.571 & 6 & Positive \\
MS12 & 0.878 & 9 & Positive \\
MS13 & 0.905 & 9 & Positive \\
MS14 & 0.788 & 9 & Positive \\
MS15 & 0.711 & 8 & Positive \\
MS16 & 1.354 & 9 & Positive \\
MS17 & 0.717 & 8 & Positive \\
MS18 & 0.881 & 9 & Positive \\
MS19 & 0.540 & 6 & Positive \\
MS20 & 0.736 & 9 & Positive \\
\hline
\end{tabular}

*Absorbance. Abs range in Table 2. ${ }^{* *}$ ELISA levels.

separated by four months, for prophylactic purposes, and after control measures against the flies had been implemented. No new cases of T. vivax infection were observed on the farm in Lins up to December 2010.

Cryptic trypanosome infections can be reactivated by stress, thus resulting in rapid spreading of the infectious agent when cattle movements along commercial routes are combined with availability of potential vectors (DWINGER; HALL, 2000). It seems that animals living in endemic area under good sanitary and nutritional conditions are able to maintain a balance with T. vivax infection (PAIVA et al., 2000; SCHENK et al., 2001). However, concomitant infections with other hemoprotozoa, nutritional and physical stress (such as transportation) and chronic and cryptic parasitism can undo this balance and favor T. vivax. The numbers of vectors and density of herds without previous contact with $T$. vivax can determine how fast $T$. vivax can spread in a herd or region, such that larger numbers of vectors and higher herd densities give rise to faster dissemination.

The data from this study demonstrated that official animal sanitary entities must search for T. vivax when animals from endemic areas are transported to areas that so far have been considered to be non-endemic for this parasite, in order to prevent new outbreaks and massive economic losses caused by the severe disease induced by $T$. vivax in naïve livestock herds.

\section{References}

Aquino LPCT, Machado RZ, Lemos KR, Marques LC, Garcia MV, Borges GP. Antigenic Characterization of Trypanosoma evansi using sera from experimentally and naturally infected bovines, equines, dogs, and coatis. Rev Bras Parasitol Vet 2010; 19(2): 112-118. http://dx.doi. org/10.4322/rbpv.01902009

Batista JS, Oliveira AF, Rodrigues CMF, Damasceno CAR, Oliveria IRS, Alves HM, et al. Infection by Trypanosoma vivax in goats and sheep in the Brazilian semiarid region: From acute disease outbreak to chronic cryptic infection. Vet Parasitol 2009; 165(1-2): 131-135. PMid:19665308. http://dx.doi.org/10.1016/j.vetpar.2009.07.005

Batista JS, Riet-Correa F, Teixeira MMG, Madruga CR, Simóes SDV, Maia TF. Trypanosomiasis by Trypanosoma vivax in cattle in the Brazilian semiarid: description of an outbreak and lesions in the nervous system. Vet Parasitol 2007; 143(2): 174-181. PMid:16965857. http://dx.doi. org/10.1016/j.vetpar.2006.08.017

Carvalho AU, Abrão DC, Facury Filho EJ, Paes PRO, Ribeiro MFB. Ocorrência de Trypanosoma vivax no estado de Minas Gerais. Arq Bras Med Vet Zootec 2008; 60(3): 769-771. http://dx.doi.org/10.1590/S010209352008000300037

Centro Integrado de Informaçôes Agrometeorológicas - CIIAGRO [online]. 2011 [cited 2011 Apr 12]. Available from: http://www.ciiagro. sp.gov.br/ciiagroonline/Listagens/BH/LBalancoHidricoLocal.asp.

Clarkson MJ. Trypanosomiasis of domesticated animals of South America. Trans R Soc Trop Med Hyg 1976; 70(2): 125-126. http://dx.doi. org/10.1016/0035-9203(76)90171-1

Clarkson MJ, McCabe W, Colina, HS. Bovine trypanosomosis in Venezuela. Trans R Soc Trop Med Hyg 1971; 65(2): 257-258. http:// dx.doi.org/10.1016/0035-9203(71)90266-5

Cortez AP, Rodrigues AC, Garcia HA, Neves L, Batista JS, Bengaly $\mathrm{Z}$, et al. Cathepsin L-like genes of Trypanosoma vivax from Africa and south America - characterization, relationships and diagnostic implications. Mol Cell Probes 2009; 23(1): 44-51. PMid:19063960. http://dx.doi.org/10.1016/j.mcp.2008.11.003

Cortez AP, Ventura RM, Rodrigues AC, Batista JS, Paiva F, Añez N, et al. The taxonomic and phylogenetic relationships of Trypanosoma vivax from South America and Africa. Parasitology 2006; 133(2): 159-169. PMid:16650339. http://dx.doi.org/10.1017/S0031182006000254

Cuglovici DA, Bartholomeu DC, Reis-Cunha JL, Carvalho AU, Ribeiro MF. Epidemiologic aspects of an outbreak of Trypanosoma vivax in a dairy cattle herd in Minas Gerais state, Brazil. Vet Parasitol 2010; 169(3-4): 320-326. PMid:20138431. http://dx.doi. org/10.1016/j.vetpar.2009.12.041

Da Silva AS, Garcia Perez HA, Costa MM, França RT, De Gasperi D, Zanette RA, et al. Horses naturally infected by Trypanosoma vivax in 
southern Brazil. Parasitol Res 2011; 108(1): 23-30. PMid:20820805. http://dx.doi.org/10.1007/s00436-010-2036-2

Da Silva AS, Costa MM, Polenz MF, Polenz CH, Teixeira MMG, Lopes STA, et al. Primeiro registro de Trypanosoma vivax em bovinos no Estado do Rio Grande do Sul, Brasil. Ciência Rural 2009; 39(8): 2550-2554. http://dx.doi.org/10.1590/S0103-84782009005000189

Dadour IR, Voss SC. Investigation of the factors affecting adult fly production in biosolid cake. Environ Entomol 2009; 38(3): 633-638. PMid:19508771. http://dx.doi.org/10.1603/022.038.0314

Dávila AMR, Herrera HM, Schlebinger T, Souza SS, Traub-Cseko YM. Using PCR for unraveling the cryptic epizootiology of livestock trypanosomosis in the Pantanal, Brazil. Vet Parasitol 2003; 117(1-2): 1- 13. http://dx.doi.org/10.1016/j.vetpar.2003.08.002

Desquesnes M, Gardiner PR. Epidémiologie de la trypanosome bovine (Trypanosoma vivax) en Guyane Française. Rev Elev Med Vet Pays Trop 1993; 46(3): 463-470. PMid:7910693.

Dwinger RH, Hall MJR. Trypanosomosis due to Trypanosoma vivax in ruminants in Latin America: a review. In: Food and Agriculture Organization of the United Nations - FAO. Animal Trypanosomosis: diagnosis and epidemiology. Leiden: Netherlands; 2000. p. 51-58.

Garcia H, Garcia ME, Perez H, Mendoza-Leon A. The detection and PCR-based characterization of the parasites causing trypanosomiasis in water-buffalo herds in Venezuela. Ann Trop Med Parasitol 2005; 99(4): 359-370. PMid:15949183. http://dx.doi. org/10.1179/136485905X36271

Gardiner PR. Recent studies of the biology of Trypanosoma vivax. Adv Parasitol 1989; 28: 229-317. http://dx.doi.org/10.1016/S0065308X(08)60334-6

Jones TW, Dávila AMR. Trypanosoma vivax - out of Africa. Trends Parasitol 2001; 17(2): 99-101. http://dx.doi.org/10.1016/S14714922(00)01777-3

Machado RZ, Montassier HJ, Pinto AA, Lemos EG, Machado MRF, Valadão IFF, et al. An enzyme-linked immunosorbent assay (Elisa) for detection of antibodies against Babesia bovis in cattle. Vet Parasitol 1997; 71(1): 17-26. http://dx.doi.org/10.1016/S03044017(97)00003-4

Murray M, Dexter TM. Anemia in bovine African trypanosomiasis. A review. Acta Trop 1998; 45(4): 389-432.

Oda FH, Arantes CA. Surto populacional da mosca dos estábulos Stomoxys calcitrans, Linnaeus, 1758 (DIPTERA: MUCIDAE) no município de Planalto, SP. Rev Agroneg Meio Ambiente 2010; 3(1): 145-159.

Oliveira JB, Hernandéz-Gamboa J, Jiménez-Alfaro C, Zeledón R, Blandón M, Urbina A. First report of Trypanosoma vivax infection in dairy cattle from Costa Rica. Vet Parasitol 2009; 163(1-2): 136-139. PMid:19414224. http://dx.doi.org/10.1016/j.vetpar.2009.03.051

Osório ALAR, Madruga CR, Desquesnes M, Soares CO, Ribeiro LRR, Costa SCG. Trypanosoma (Duttonella) vivax: its biology, epidemiology, pathogenesis, and introduction in the New World-a review. Mem Inst Oswaldo Cruz 2008; 103(1): 1-13. PMid:18368231.

Otte MJ, Abuabara JY, Wells EA. Trypanosoma vivax in Colombia: epidemiology and production losses. Trop Anim Health Prod 1994; 26(3): 146-156. PMid:7809986. http://dx.doi.org/10.1007/ BF02241071
Paiva F, Lemos RAA, Nakasato L, Mori AE, Brum KB, Bernardo KC. Trypanosoma vivax em bovinos no pantanal do estado do Mato Grosso do Sul, Brasil: I Acompanhamento clínico, laboratorial e anatomopatológico de rebanhos infectados. Rev Bras Parasitol Vet 2000; 9(2): 135-141.

Quispe PA, Chávez AV, Casa EA, Trigueros AV, Suárez FA. Prevalencia de Trypanosoma vivax en bovinos de la província de Coronel Portillo, Ucayali. Rev Inv Vet Perú 2003; 14(2): 161-165.

Radostits OM, Gay CC, Hinchcliff KW, Constable PD. Reference laboratory values. In: Radostits OM, Gay CC, Hinchcliff KW, Constable PD. Veterinary Medicine. Philadelphia: Saunders. 2007. p. 2047.

Rodríguez-Batista Z, Leite RC, Oliveira PR, Lopes CML, Borges LMF. Populational dynamics of Stomoxys calcitrans (Linneaus) (Diptera: Muscidae) in three biocenosis, Minas Gerais, Brazil. Vet Parasitol 2005; 130(3-4): 343-346. PMid:15908125. http://dx.doi.org/10.1016/j. vetpar.2005.03.006

Seidl AF, Silva RAMS, Abreu UGP, Pellegrin AO. Estimated cost of a Trypanosoma vivax outbreak on blood cattle in the Pantanal (Brazil). Mem Inst Oswaldo Cruz 1997; 92(Supl. 1): 269-272.

Schenk MAM, Mendonça CL, Madruga CR, Kohayagawa A, Araújo, FR. Avaliação clínico-laboratorial de bovinos nelore infectados experimentalmente com Trypanosoma vivax. Pesq Vet Bras 2001; 21(4): 157-161. http://dx.doi.org/10.1590/S0100-736X2001000400006

Silva RAMS, Dávila AMR. Bovine trypanosomosis due to Trypanosoma vivax in the German Bush province, Bolivia. Parasitol Día 2001; 25(1-2): 92-95.

Silva RAMS, Eguez A, Morales G, Eulert E, Montenegro A, Ybañez $\mathrm{R}$, et al. Bovine trypanosomiasis in Bolivian and Brazilian lowlands. Mem Inst Oswaldo Cruz 1998a; 93(1): 29-32. http://dx.doi.org/10.1590/ S0074-02761998000100006

Silva RAMS, Morales, G, Eulert E, Montenegro A, Ybañez, R. Outbreaks of trypanosomosis due to Trypanosoma vivax in cattle in Bolivia. Vet Parasitol 1998b; 76(1-2): 153-157. http://dx.doi.org/10.1016/S03044017(97)00005-8

Silva RAMS, Silva JA, Schneider RC, Freitas J, Mesquita D, Mesquita $\mathrm{T}$, et al. Outbreak of trypanosomiasis due to Trypanosoma vivax (Ziemann, 1905) in bovines of the Pantanal, Brazil. Mem Inst Oswaldo Cruz 1996; 91(5): 561-562. http://dx.doi.org/10.1590/S007402761996000500005

Tamasaukas R, Ruiz H, Aguirre A, Roa N, Cobo M, Aso PM. Agriecoepidemiology of trypanosomosis due Trypanosoma vivax in ruminants of some farms located in Venezuela: technical note. Rev Cientifica FCV-LUZ 2000; 10(6): 453-457.

Ventura RM, Paiva F, Silva RAMS, Takeda GF, Buck GA, Teixeira MMG. Trypanosoma vivax: characterization of the spliced-leader gene for a Brazilian stock and species-specific detection by PCR amplification of an intergenic spacer sequence. Exp Parasitol 2001; 99(1): 37-48. PMid:11708832. http://dx.doi.org/10.1006/expr.2001.4641

Woo PTK. The haematocrit centrifuge technique for the diagnosis of African trypanosomiasis. Acta Trop 1970; 27(4): 384-386. PMid:4396363. 